\title{
Implementasi Pembelajaran PBL Berbantuan Media Kartu Soal Untuk Meningkatkan Kemampuan HOTS Pada Siswa Kelas VI SD
}

Ni Nyoman Arca Aspini

SD Negeri 2 Banyuning arcaaspini@gmail.com

\author{
A R T I C L E I N F O \\ Article history: \\ 1 Januari 2020 Received in \\ revised form \\ 30 Mei 2020 \\ Accepted 30 Juni 2020 \\ Available online \\ 15 Juli 2020 \\ Kata Kunci: \\ $P B L$, kartu soal, kemampuan \\ HOTS \\ Keywords: \\ $P B L$, question cards, HOTS \\ ability
}

\begin{abstract}
ABSTRAK
Salah satu kendala yang dialami siswa dalam pelaksanaan pembelajaran hingga saat ini adalah kurangnya kemampuan siswa dalam berpikir tingkat tinggi (Higher Order thinking skill) untuk memecahkan permasalahan yang diajukan guru dalam proses pembelajaran dikelas. Hal ini tidak terkecuali pada siswa kelas VI SD khususnya pada mata pelajaran matematika. Untuk menangani masalah tersebut perlu dilakukan upaya untuk meningkatkan kemampuan berpikir tingkat tinggi siswa. Penelitian ini adalah penelitian tindakan kelas yang dilaksanakan dalam 2 siklus. Penelitian ini bertujuan untuk meningkatkan kemampuan
\end{abstract} berpikir tingkat tinggi pada siswa kelas VI SD melalui implementasi pembelajaran PBL berbantuan media kartu soal. Rancangan masing-masing siklus terdiri dari perencanaan, pelaksanaan, observasi/evaluasi dan refleksi. Penelitian ini menemukan bahwa implementasi pembelajaran PBL berbantuan media kartu soal dapat meningkatkan kemampuan HOTS siswa kelas VI SD. Hal ini terlihat dari ratarata kemampuan HOTS siswa prasiklus sebesar 63,89 yang berada pada kategori kurang, siklus I sebesar 71,09 yang berada pada kategori cukup, dan meningkat pada siklus II sebesar 79,20 yang berada pada kategori baik

\begin{abstract}
AB S T R A K
One obstacle experienced by students in the implementation of learning now is the lack of students' ability to think at a higher level (Higher Order thinking skills) to solve problems raised by teachers in the learning process in class. This was no exception for students in grade VI, especially in mathematics. To deal with these problems efforts need to be made to improve students' higher-order thinking skills. This research was a classroom action research conducted in 2 cycles. The aimed of this research was to improve the ability of higher order thinking skill on grade VI elementary school students through the implementation of PBL learning aided by the question card media. The design of each cycle consisted of planning, implementation, observation / evaluation and reflection. This research found that the implementation of PBL learning assisted by the question card media could improve the ability of HOTS grade VI elementary school students. This could be seen from the average ability of HOTS on pre-cycle students of 63.89 who were in the poor category, the first cycle of 71.09 that was in the moderate category, and increased in the second cycle of 79.20 which was in the good category.
\end{abstract}

\section{PENDAHULUAN}

Undang-Undang Nomor 20 Tahun 2003 tentang Sistem Pendidikan Nasional telah mengadopsi taksonomi dalam bentuk rumusan sikap, pengetahuan, dan keterampilan. Peraturan Menteri Pendidikan dan Kebudayaan nomor 20 tahun 2016 tentang Standar Kompetensi Lulusan Pendidikan Dasar dan Menengah mengamanatkan bahwa dimensi 
keterampilan siswa dituntut memiliki keterampilan menalar, mengolah, dan menyaji secara kreatif, produktif, kritis, mandiri, kolaboratif, dan komunikatif dalam ranah konkret dan ranah abstrak sesuai dengan yang dipelajari di sekolah dan sumber lain yang sama dalam sudut pandang teori.

Peraturan Menteri Pendidikan dan Kebudayaan Nomor 21 Tahun 2016 tentang Standar Isi Pendidikan Dasar dan Menengah (BSNP, n.d.) menguraikan bahwa ketiga ranah kompetensi tersebut memiliki lintasan perolehan (proses psikologis) yang berbeda. Sikap diperoleh melalui aktivitas "menerima, menjalankan, menghargai, menghayati, dan mengamalkan". Pengetahuan diperoleh melalui aktivitas "mengingat, memahami, menerapkan, menganalisis, mengevaluasi, mencipta". Keterampilan diperoleh melalui aktivitas "mengamati, menanya, mencoba, menalar, menyaji, dan mencipta".

Peraturan Menteri Pendidikan dan Kebudayaan Nomor 22 Tahun 2016 (BSNP, n.d.) tentang Standar Proses Pendidikan Dasar dan Menengah berbicara tentang proses Pembelajaran pada satuan pendidikan diselenggarakan secara interaktif, inspiratif, menyenangkan, menantang, memotivasi siswa untuk berpartisipasi aktif, serta memberikan ruang yang cukup bagi prakarsa, kreativitas, dan kemandirian sesuai dengan bakat, minat, dan perkembangan fisik serta psikologis siswa.

Berdasarkan uraian di atas, kurikulum 2013 menuntut agar siswa selain memiliki sikap dan pengetahuan yang baik juga dituntut memiliki keterampilan menalar, mengolah, dan menyaji secara kreatif, produktif, kritis, mandiri, kolaboratif, dan komunikatif dalam ranah konkret dan ranah abstrak melalui rangkaian pembelajaran mengamati, menanya, mencoba, menalar, menyaji, dan mencipta. Tugas guru adalah mengembangkan keterampilan-keterampilan tersebut secara interaktif, inspiratif, menyenangkan, menantang, memotivasi siswa untuk berpartisipasi aktif, kreatif dan mandiri sesuai perkembangan fisik dan psikologis siswa.

Berkenaan dengan hal tersebut, berdasarkan observasi yang dilakukan dikelas VI SD Negeri 2 Banyuning pada mata pelajaran matematika diperoleh fakta bahwa (1) siswa yang menonjol dikelas kecenderungan adalah siswa yang sama disetiap pertemuan, (2) siswa yang terampil menyelesaikan soal disetiap pertemuan kurang memiliki kesadaran berbagi dengan temannya, (3) siswa masih kesulitan dalam memahami soal, (4) siswa belum bisa memisahkan bagian-bagian penting dalam soal untuk dijadikan kunci menyelesaikan soal, (5) siswa belum terampil dalam mengerjakan hal-hal baru yang belum dicontohkan oleh guru, (6) nilai awal siswa dalam mengerjakan soal HOTS (kategori soal menganalisis) dengan nilai rata-rata kelas 63,89. Dikesempatan lain, pada saat dialog awal yang dilakukan dengan guru mata pelajaran, berdasarkan permasalahanpermasalahan yang terjadi serta tuntutan keterampilan yang harus dikuasai siswa dalam kurikulum 2013 yang diembankan kepada guru, diperoleh kesepakatan bahwa perlu diterapkan pembelajaran dengan memberikan soal-soal yang menantang bagi siswa agar siswa semakin terampil dan lebih memiliki kesempatan untuk siswa mengekspolari lagi pengetahuan yang mereka miliki, tapi juga dikemas dengan strategi pembelajaran yang menyenangkan agar siswa tidak bosan dan lebih menyukai matematika apapun materinya.

Dengan diberlakukannya kurikulum 2013 yang menekankan kepada siswa untuk dapat mengembangkan kemampuan berpikirnya sendiri maka pendidik/guru harus mampu merancang dan mengembangkan pembelajaran sehingga siswa terlatih untuk bisa memprediksi, mendesain, dan memperkirakan solusi atas suatu permasalahan yang ada di kehidupan nyata. Oleh karena itu, keterampilan berpikir tingkat tinggi akan menjadi modal pada jenjang pendidikan. Menurut Rofiah (2013:17) High Order Thinking Skills (HOTS) didefinisikan sebagai penggunaan pikiran secara lebih luas untuk menemukan tantangan baru. HOTS atau berpikir tingkat tinggi merupakan proses berpikir tidak sekedar menghafal dan menyampaikan kembali informasi yang diketahui. Kemampuan berpikir tingkat tinggi merupakan kemampuan menghubungkan, memanipulasi dan mentransformasi pengetahuan serta pengalaman yang sudah dimiliki untuk berpikir 
secara kritis dan kreatif dalam upaya menentukan keputusan dan memecahkan masalah pada situasi baru.

Berbagai macam model pembelajaran telah dikembangkan untuk memaksimalkan daya nyaman siswa dalam belajar dan mengembangkan keterampilan berpikir mereka, salah satu model yang ditawarkan dalam kurikulum 2013 adalah model pembelajaran Problem Based Learning (PBL). Model PBL menurut (Marina, 2008) adalah pendekatan pembelajaran yang berpusat pada konstruktivisme pada siswa dengan berdasarkan analisis, resolusi dan diskusi tentang masalah yang diberikan. (Susanto, 2016) berpendapat bahwa keterampilan dalam berpikir dapat dikembangkan dengan perlakuan khusus untuk melatih proses berpikir agar memasuki memori penyimpanan jangka panjang, sehingga pengetahuan yang didapatkan akan lebih bermakna. Wulandari, dkk (2013) menyatakan bahwa penerapan model PBL dapat meningkatkan motivasi siswa dalam belajar sehingga berpengaruh pada hasil belajar siswa. Nafiah (2014:125) juga menyatakan bahwa "penerapan PBL dalam proses pembelajaran dapat meningkatkan hasil belajar siswa sebesar 31,03\%". Penelitian yang dilakukan oleh Shofiyah dan Fitria (2018)menyatakan bahwa penerapan model pembelajaran PBL dapat memfasilitasi siswa dalam mengembangkan penalaran ilmiah. Rahayu (2017) juga menyatakan bahwa penerapan model PBL meningkatkan prestasi siswa dalam belajar sehingga membuat pembelajaran menjadi efektif. Berdasarkan penelitian tersebut dapat disimpulkan bahwa model pembelajaran PBL dapat meningkatkan motivasi dan minat siswa dalam belajar sehingga meningkatkan hasil belajar siswa.

Problem based learning yang dalam bahasa Indonesia dikenal dengan model pembelajaran berbasis masalah ini diangkat sebab ditinjau secara umum terdiri dari menyajikan situasi masalah yang autentik dan bermakna yang dapat memberikan kemudahan untuk melakukan penyelidikan. Model pembelajaran berbasis masalah merupakan suatu model pembelajaran yang didasarkan pada banyaknya permasalahan yang membutuhkan penyelidikan autentik yakni penyelidikan yang membutuhkan penyelesaian nyata dari permasalahan yang nyata (Trianto, 2009:91). Kartu soal dalam pembelajaran yang dibuat agar menumbuhkan minat belajar siswa, hal ini dilakukan menurut hasil penelitian (DePorter, Bobbi and Hernacki, 2011:110) yang berpendapat bahwa setiap orang mempunyai gaya belajar yang berbeda-beda, dan gaya belajar yang melibatkan visualisasi objek akan lebih memudahkan siswa dalam belajar. Penelitian yang dilakukan oleh Halimah (2019) juga menyatakan bahwa kartu gambar dapat diterapkan untuk meningkatkan kemampuan membaca pada anak tunagrahita ringan. Dony, dkk (2018) menyatakan bahwa pengunaan media kartu dapat meningkatkan motivasi siswa dalam belajar, ketrampilan berpikir, dan kejujuran siswa sehingga meningkatkan hasil belajar siswa. Hasil belajar siswa akan lebih baik menggunakan media kartu daripada tanpa menggunakan media kartu (Lestari, 2018).

Tuntutan keterampilan berpikir dalam kurikulum 2013 ini sejalan dengan pendapat Anderson, L.W dan Krathwohl (2010) mengadopsi ranah berpikir Bloom mengkategorikan indikator untuk mengukur keterampilan berpikir tinggi meliputi menganalisis, mengevaluasi dan mencipta/mengkreasi: (1) menganalisis: siswa terampil dalam memisahkan materi menjadi bagian-bagian penyusunannya dan mendeteksi bagaimana suatu bagian berhubungan dengan satu bagiannya yang lain; (2) mengevaluasi: siswa terampil dalam membuat keputusan berdasarkan kreteria yang standar (3) mencipta: siswa terampil dalam merencanakan suatu cara untuk membuat rancangan untuk menyelesaikan suatu tugas yang diberikan dan menyelesaikannya.

Dalam pembelajaran berbasis masalah, siswa menemukan suatu konsep pengetahuan melalui serangkaian keterampilan proses. Melalui proses tersebut, siswa akan didorong untuk terlibat secara langsung dan aktif dalam mempelajari suatu konsep materi pelajaran. Pembelajaran dengan pendekatan ini juga akan mengasah keterampilan proses siswa. Seperti yang sudah diketahui bahwa keterampilan proses merupakan bekal yang bisa digunakan untuk menemukan suatu konsep atau pengetahuan. 
Penggunaan pembelajaran PBL berbantuan media kartu soal dapat memicu keterlibatan siswa secara langsung dalam pembelajaran sehingga akan meningkatkan kemampuan berpikir tingkat tinggi siswa. Diharapkan dengan implementasi pembelajaran PBL berbantuan media kartu soal dapat meningkatkan kemampuan HOTS siswa.

Rumusan masalah dalam penelitian ini adalah: Apakah implementasi pembelajaran PBL berbantuan media kartu soal dapat meningkatkan kemampuan HOTS pada siswa kelas VI SD Negeri 2 Banyuning semester II tahun pelajaran 2019/2020?

Tujuan penelitian tindakan kelas ini adalah untuk meningkatkan kemampuan HOTS pada siswa kelas VI SD Negeri 2 Banyuning semester II tahun pelajaran 2019/2020 melalui implementasi pembelajaran PBL berbantuan media kartu soal.

\section{METODE PENELITIAN}

Tempat penelitian tindakan kelas adalah kelas VI di SD Negeri 2 Banyuning, Kecamatan Buleleng, Kabupaten Buleleng. Waktu penelitian dilaksanakan pada semester II tahun pelajaran 2019/2020. Subjek dalam penelitian tindakan kelas ini adalah seluruh siswa kelas VI SD Negeri 2 Banyuning yang berjumlah 35 orang yang terdiri dari 21 orang siswa laki-laki dan 14 orang siswa perempuan. Objek dalam penelitian ini adalah kemampuan HOTS siswa.

Penelitian ini merupakan penelitian tindakan kelas (PTK), yang terdiri dari "kegiatan perencanaan, tindakan, observasi/evaluasi dan refleksi" (Dantes Nyoman, 2012:137) Uraian kegiatan masing-masing tahapan tampak di bawah ini.

Pada tahap perencanaan, beberapa kegiatan yang akan dilakukan pada siklus I adalah menetapkan Kompetensi Dasar (KD), serta indikator yang akan digunakan dalam penelitian, menyiapkan materi pembelajaran berdasarkan topik yang akan diberikan untuk setiap pertemuan, membuat RPP, menyiapkan media kartu soal, dan menyiapkan instrument penilaian.

Pada tahap tindakan, dilaksanakan proses pembelajaran sesuai dengan rencana pembelajaran (RPP) yang sudah dipersiapkan. Pertemuan yang dilakukan dalam satu siklus adalah sebanyak 3 kali, 2 kali tatap muka dan 1 kali tes akhir siklus.

Tahap observasi/evaluasi dilakukan untuk mengamati segala kegiatan yang dilakukan oleh guru dan siswa dalam proses pembelajaran. Aktivitas siswa yang telah diamati akan dicatat dalam dokumen observasi. Pada akhir siklus diadakan evaluasi akhir siklus.

Tahap refleksi dilakukan untuk mengkaji kemampuan HOTS. Tujuan refleksi adalah untuk membangun kekuatan-kekuatan yang ditemukan, kelemahan-kelamahan, dan hambatan-hambatan yang dialami dalam mencapai tujuan yang diharapkan. Hasil refleksi ini dapat digunakan sebagai dasar atau acuan untuk memperbaiki dan menyempurnakan tahap-tahapan penelitian pada siklus selanjutnya. Pelaksanaan tindakan akan dihentikan, apabila hasil evaluasi telah menunjukkan hasil yang ingin dicapai.

Untuk data kemampuan HOTS siswa dikumpulkan dengan menggunakan metode tes. Tes yang digunakan adalah tes pilihan ganda. Data dalam penelitian ini dianalisis menggunakan metode analisis deskriptif kuantitatif. Analisis data dilakukan setelah seluruh data diperoleh. Agung (2011:60) menyatakan, "metode analisis deskriptif kuantitatif ialah suatu cara pengolahan data yang dilakukan dengan jalan menyusun secara sistematis dalam bentuk angka-angka dan atau persentase mengenai suatu objek yang diteliti sehingga diperoleh kesimpulan umum. Untuk mencari mencari mean atau rata-rata digunakan rumus sebagai berikut.

$$
\mathrm{M}=\frac{\sum \mathrm{X}}{\mathrm{n}}
$$


Keterangan :

M : Rerata

$\mathrm{X}$ : Skor hasil belajar

$\mathrm{N}$ : Jumlah siswa

Selanjutnya, untuk mengetahui persentase rata-rata skor digunakan rumus sebagai berikut.

$$
\mathrm{M} \%=\frac{\mathrm{M}}{\mathrm{SMI}} \times 100 \%
$$

Keterangan :

$\mathrm{M} \%=$ Rata-rata persen

$\mathrm{M} \quad=$ Rata-rata skor

SMI = Skor Maksimal Ideal

Hasil analisis persentase rata-rata yang diperoleh selanjutnya dikonversikan ke dalam Penilaian Acuan Patokan (PAP) skala lima untuk mengetahui tingkat kriteria hasil belajar. Adapun pedoman yang digunakan dapat dilihat pada tabel 3.2 berikut ini.

Tabel 01. Pedoman Konversi Penilaian Acuan Patokan (PAP) Skala Lima

\begin{tabular}{c|c}
\hline Persentase $(\%)$ & Kriteria \\
\hline $90-100$ & Sangat Baik \\
$75-89$ & Baik \\
$65-74$ & Cukup \\
$40-64$ & Kurang \\
$0-39$ & Sangat Kurang \\
\hline
\end{tabular}

Kriteria kemampuan HOTS siswa dalam penelitian ini adalah bila kemampuan HOTS siswa mencapai tingkat kriteria minimal $75 \%$ (baik).

\section{HASIL DAN PEMBAHASAN}

\section{HASIL}

Berdasarkan hasil analisis sebelum penelitian (prasiklus) artinya kemampuan HOTS siswa sebelum implementasi pembelajaran PBL berbantuan media kartu soal pada siswa kelas VI SD Negeri 2 Banyuning, diperoleh rata-rata sebesar 63,89 yang kemudian digunakan untuk menghitung rata-rata persen, untuk mengetahui tingkat kemampuan HOTS siswa. Setelah nilai rata-rata persen sebesar 63,89\% dikonversikan dengan PAP skala lima, maka tingkat kemampuan HOTS siswa pada prasiklus tergolong kurang (40 64). Berdasarkan data di atas, maka perlu ada suatu perubahan dalam pembelajaran. Untuk meningkatkan kemampuan HOTS siswa kelas VI SD Negeri 2 Banyuning Tahun Pelajaran 2019/2020, maka diterapkan pembelajaran PBL berbantuan media kartu soal.

Penelitian siklus 1 dilaksanakan dalam 3 kali pertemuan yaitu 2 kali pertemuan untuk pelaksanaan tindakan dan 1 kali pertemuan dilaksanakan tes untuk mengukur kemampuan HOTS siswa. Alokasi setiap pertemuan adalah 3 x 35 menit. Materi yang dipelajari pada siklus I adalah tema 6 sub tema 1 Siswa diberikan kartu soal, kemudian siswa menjawab soal tersebut berdasarkan materi yang dipelajari dalam proses pembelajaran yang menggunakan model pembelajaran PBL. Hasil dari siklus I berupa kemampuan HOTS yang diperoleh dari tes tertulis. Tes tulis yang digunakan berupa tes objektif pilihan ganda. Data kemampuan HOTS dianalisis untuk mengetahui hasil penelitian. 
Berdasarkan hasil analisis data diperoleh rata-rata kemampuan HOTS siswa sebesar 71,09 yang kemudian digunakan untuk menghitung rata-rata persen untuk mengetahui tingkat kemampuan HOTS siswa. Nilai rata-rata persen sebesar 71,09\% dikonversikan dengan PAP skala lima, maka tingkat kemampuan HOTS siswa pada siklus I tergolong cukup ( 65 - 74). Karena belum mencapai kriteria keberhasilan, maka penelitian dilanjutkan ke siklus II.

Ada beberapa hal yang menyebabkan belum tercapainya target yang ditetapkan dalam penelitian ini yaitu siwa belum terbiasa untuk berpikir tingkat tinggi. Hal ini diatasi dengan memberikan pemahaman kepada siswa tentang pentingnya kemampuan HOTS. Kemampuan siswa berbeda, sehingga siswa yang memiliki kemampuan yang bagus akan mudah menganalisis stimulus, sedangkan siswa yang memiliki kemampuan kurang akan lebih sulit. Hal ini diatasi dengan memberikan perhatian lebih kepada siswa yang kurang dengan memberikan penjelasan tentang bagaimana cara menganalisis stimulus yang diberikan. Pada saat bekerja dalam kelompok, tidak semua aktif dalam mengerjakan tugas. Hal ini diatasi dengan memberikan motivasi kepada siswa agar mau bekerja aktif dalam kelompok. Hanya beberapa siswa yang berani mengajukan pertanyaan. Hal ini diatasi dengan cara memotivasi siswa agar mau bertanya apabila mengalami kendala.

Penelitian siklus II dilaksanakan dalam 3 kali pertemuan yaitu 2 pertemuan untuk pelaksanaan tindakan dan 1 pertemuan untuk melaksanakan tes untuk mengukur kemampuan HOTS siswa. Materi yang dipelajari pada siklus II adalah tema 6 sub tema 3. Berdasarkan hasil analisis data diperoleh nilai rata-rata kemampuan HOTS siswa sebesar 79,20 yang kemudian digunakan untuk menghitung rata-rata persen, untuk mengetahui tingkat kemampuan HOTS siswa. Setelah nNilai rata-rata persen dikonversikan dengan PAP skala lima, maka tingkat kemampuan HOTS siswa pada siklus II tergolong baik (75 - 89). Karena telah mencapai kriteria keberhasilan, maka penelitian dihentikan sampai siklus II.

Berdasarkan hasil analisis data pada siklus II tingkat kemampuan HOTS siswa mencapai $79,20 \%$ yang tergolong baik. Untuk itu penelitian ini sudah sesuai dengan target sehingga penelitian dihentikan sampai dengan siklus II. Berdasarkan hasil analisis data hasi penelitian secara keseluruhan, dapat dilihat pada tabel berikut.

Tabel 02: Rekap Hasil Penelitian

\begin{tabular}{c|c|c|c|c}
\hline \multirow{2}{*}{ No } & \multirow{2}{*}{ Siklus } & \multicolumn{3}{|c}{ Hasil Belajar } \\
\cline { 3 - 5 } & & Rata-Rata & Rata-Rata Persen & Kriteria \\
\hline 1 & Pra & 63,89 & $63,89 \%$ & Kurang \\
2 & I & 71,09 & $71,09 \%$ & Cukup \\
3 & II & 79,20 & $79,20 \%$ & Baik \\
\hline
\end{tabular}

Berdasarkan tabel di atas terlihat terjadi peningkatan kemampuan HOTS siswa kelas VI SD Negeri 2 Banyuning dari pra siklus ke siklus I dan ke siklus II. Dengan demikian implementasi pembelajaran PBL berbantuan media kartu soal dapat meningkatkan kemampuan HOTS siswa kelas VI SD Negeri 2 Banyuning semester II tahun pelajaran 2019/2020.

\section{PEMBAHASAN}

Melalui implementasi media kartu soal dalam PBL siswa berlatih berpikir tingkat tinggi untuk menemukan konsep yang dipelajari melalui belajar dalam kelompok kecil dan strategi pembelajaran berpikir tingkat tinggi. Siswa mulai dengan kegiatan menganalisis, mengevaluasi, dan mengkreasi. Implementasi media kartu soal dalam PBL memberikan kesempatan kepada siswa untuk mengkonstruksi sendiri pengetahuannya berdasarkan pengetahuan awal yang telah dimiliki. Melalui kartu soal siswa menganalisis soal yang diberikan, kemudian siswa menjawab sesuai dengan pemahaman mereka 
terhadap soal tersebut. Siswa belajar memecahkan masalah sesuai dengan materi yang dipelajari, sehingga mereka mampu menguasainya. Keterampilan tingkat tinggi yang lebih dikenal dengan istilah HOTS, sangat diperlukan dalam memahami materi-materi yang ada pada Kurikulum 2013 yang menuntut siswa mampu menganalisis, mengevaluasi, dan mengkreasi. Hal ini sejalan dengan penelitian yang dilakukan oleh Putri (2019) yang menyatakan bahwa penggunaan media papan kartu dapat meningkatkan hasil belajar siswa. Mulyani (2017) juga menyatakan bahwa pengunaan media kartu dapat meningkatkan ketrampilan dan hasil belajar siswa $86,1 \%$. Model pembelajaran berbasis masalah merupakan salah satu dari berbagai model pembelajaran yang dapat digunakan guru dalam mengaktifkan siswa dalam belajar. Hal ini sejalan dengan penelitian yang dilakukan oleh Hartini (2014) menyatakan bahwa penggunaan model pembelajaran PBL dapat meningkatkan pemikiran kreatif dan hasil belajar siswa secara signifikan. Sehingga dapat disimpulkan bahwa model pembelajaran PBL dapat meningkatkan motivasi dan hasil belajar siswa.

Model pembelajaran berbasis masalah bercirikan penggunaan masalah dunia nyata. Model pembelajaran ini dapat digunakan untuk melatih dan meningkatkan keterampilan berpikir kritis dan memecahkan masalah serta untuk mendapatkan pengetahuan tentang konsep-konsep penting. Kartu soal digunakan sebaga media untuk memotivasi siswa agar bisa meningkatkan kemampuan HOTS siswa. Melalui menjawab soal yang ada di kartu soal, siswa belajar menganalisis stimulus dalam soal sehingga bisa menjawabnya. Melalui latihan menjawab soal tersebut berpengaruh pada peningkatan hasil belajar siswa.

\section{SIMPULAN DAN SARAN}

Berdasarkan analisis data dan pembahasan hasil penelitian yang telah diuraikan pada bab sebelumnya, maka dapat diambil simpulan bahwa implementasi pembelajaran PBL berbantuan media kartu soal dapat meningkatkan kemampuan HOTS siswa kelas VI SD Negeri 2 Banyuning semester II tahun pelajaran 2019/2020.

\section{DAFTAR RUJUKAN}

Agung, A. A. G. (2011). Metodologi Penelitian Pendidikan. Singaraja: Universitas Pendidikan Ganesha.

Anderson, L.W dan Krathwohl, D. R. 2010. (2010). Kerangka Landasan untuk Pembelajaran, Pengajaran dan Asesmen (Revisi Taksonomi Pendidikan Bloom). Yogyakarta: Pustaka Pelajar.

BSNP. (n.d.). Peraturan Menteri Pendidikan dan Kebudayaan Republik Indonesia Nomor 21 Tahun 2016 Tentang Standar Isi Pendidikan Dasar dan Menengah.

Dantes Nyoman. (2009). Beberapa Rujukan Skenario Pembelajaran Berbasis Student Center Learning.

Dantes Nyoman. (2012). Metode Penelitian. Yogyakarta: Andi.

DePorter, Bobbi and Hernacki, M. (2011). Quantum Learning. Bandung: Mizan Pustaka. Bandung: Mizan Pustaka.

Dony, Novrian, D. (2018). Media Pembelajaran Kimia Menggunakan Kartu. Jurnal Riset Dan Konseptual, 3(1).

Halimah. (2019). Penggunaan Media Kartu Gambar untuk Meningkatkan Kemampuan Membaca Permulaan pada Anak Tunagrahita Ringan. Jurnal Peradaban Islam, 1(1), 171-191.

Hartini, D. (2014). Pengaruh Berpikir Kreatif dengan Model Problem Based Learning (PBL) Terhadap Prestasi Belajar Fisika Siswa dengan Menggunakan Tes Open Ended. PII 3 (1). 2014, 3(1), 8-11. 
Lestari. (2018). Pengaruh Media Kartu Permainan Uno terhadap Hasil Belajar Siswa pada Materi Membandingkan Pecahan Sederhana. - Vol. 5, No. 2. Jurnal Ilmiah Pendidikan Guru Sekolah Dasar, 5(2), 193-203.

Marina, C. (2008). Problem-Based Learning And Mathematics: Possible Synergical Actions.

Mulyani, S. (2017). Penggunaan Media Kartu (Flash Card) dalam Meningkatkan Hasil Belajar Konsep Mutasi bagi Peserta Didik Kelas XII. Jurnal Profesi Keguruan, 3(2), 143-148.

Nafiah, Y. N. (2014). Penerapan Model Problem-Based Learning untuk Meningkatkan Keterampilan Berpikir Kritis dan Hasil Belajar Siswa. Jurnal Pendidikan Vokasi, 4(1), 125-145.

Putri, D. (2019). Penggunaan Media Papan Kartu Bhineka Untuk Meningkatkan Kemampuan Siswa Pada Materi Keragaman Budaya Siswa Kelas 4 SDN Tlogomas 2. Jurnal Basicedu, 3(1), 141-145.

Rahayu, S. (2017). Penerapan Model Problem Based Learning (PBL) untuk Meningkatkan Keterampilan Berpikir Kritis dan Prestasi Belajar Siswa (Studi pada Mata Pelajaran IPA Kelas V Pada SDN Gugus II Raflesia Talang Empat Kabupaten Bengkulu Tengah). Jurnal Ilmiah Teknologi Pendidikan, $7(2), 98-110$.

Rofiah, E. dkk. (2013). Penyusunan Instrumen Tes Kemampuan Berpikir Tingkat Tinggi Fisika pada Siswa SMP. Jurnal Pendidikan Fisika, 1, 17.

Shofiyah, F. (2018). Model Problem Based Learning (PBL) dalam Melatih Scientific Reasoning Siswa. Jurnal Penelitian Pendidikan IPA, 3(1), 33-38.

Susanto, A. (2016). Teori Belajar \& Pembelajaran di Sekolah Dasar. Jakarta: Prenadamedia Group.

Trianto. (2009). Mendesain Model Pembelajaran Inovatif Progresif. Surabaya: Kencana.

Wulandari, D. (2013). Pengaruh Problem-Based Learning Terhadap Hasil Belajar ditinjau dari Motivasi Belajar PLC di SMK. Urnal Pendidikan Vokasi, 3(2). 